\title{
Comestáa \\ Teaching information literacy to 11-16-year-old teenage members of public libraries of Tehran 1st region
}

\author{
Kiarash Mirzakhani \\ PhD student; Faculty of nursing and midwifery, Shahid Beheshti University of Medical Sciences, Tehran, \\ Iran; \\ K_mirzakhani@sbmu.ac.ir \\ Anahita Dashti \\ PhD student; Faculty of nursing and midwifery, Shahid Beheshti University of Medical Sciences, Tehran, \\ Iran; \\ a_dashti@sbmu.ac.ir
}

\begin{abstract}
Teaching information literacy is a new important issue, which has received lots of attention from most organizations and different institutions of Iran. Public libraries in different countries of the world have also paid attention to this important issue. The aim of this research is to teach information literacy to 11-16-year-old teenage members of public libraries of Tehran 1st region. This is a descriptive study conducted using survey method. The statistical population of the research consisted of teenage members (11-16 years old) of Shahid Bahonar public library, who are more than 500 individuals. Using Morgan table, research sample size was calculated to be 217 . Data were collected using researcher-made questionnaire. The collected data were analyzed by descriptive and inferential statistics. Research findings showed that the information literacy skills of 11-16-year-old teenage members of public libraries of Tehran 1st region (3.38) are higher than average (3) and the role of information literacy in teaching information literacy to teenagers (2.5) is lower than average (3).
\end{abstract}

Keywords: Public libraries. Information literacy. Teaching information literacy. Lifelong learning.

\section{Introduction}

Information literacy is considered to be a social cultural practice in the world (LLOYD, 2010), therefore, it is more appropriate to focus on research that fits the concepts of information literacy with Iranian culture and society. Misinterpretation of information literacy in specific contexts seems to lead to inaccurate assessment and ineffective training. Information literacy in the 
modern age is not just information search and locating skills, but a combination of knowledge, attitude and skills (HORTON, 2007). In the previous generation of standards, information literacy was a set of skills that could be accessed through staged training (AMERICAN SCHOOL LIBRARIANS ASSOCIATION AND EDUCATIONAL TECHNOLOGY AND COMMUNICATION ASSOCIATION, 1998). Never standards, however, include a more flexible space for information literacy development (AMERICAN UNIVERSITY LIBRARIES BOARD, 2016; AMERICAN SCHOOL LIBRARIANS ASSOCIATION, 2007).

The prerequisite for success in this era is having capabilities by which the individual can detect information need, select the most appropriate resource of information from the mass of information to meet his specific information need, locate and assess his required information, and finally, use them. Having this type of skills and capabilities is defined as information literacy (KHALEGHI; SIYAMAK, 2010) and UNESCO announced that people would be considered as illiterate if they were not familiar with a foreign language and information literacy by 2000 .

Teenagers are regarded as the intellectual and information capitals of a country, and in this digital era, they need to information literacy skills to gain access to their required information among the mass of the existing information more than ever.

Considering the importance and necessity of learning information literacy in the information era, the information literacy standards in 2006 were codified based on the experiences and international cooperation, including three components: access, evaluation, and use of information. These standards were proposed by IFLA.

The access component in information literacy is defined as a set of skills by which the user gains access to information in an efficient and effective way. Additionally, this component includes the determination and expression of information needs, and information searching and locating. The evaluation component in information literacy includes a set of skills by which the user assesses information critically and skillfully. These skills include evaluating 
and organizing information. The use of information component includes a set of skills by which the user uses information correctly and creatively. It includes the legal and ethical aspects of the use of information (LAU, 2006).

Public libraries are an integral part of a knowledge-oriented society that provide services by collecting, organizing, and distributing information resources for all age groups without any discrimination. With the advances in the new information and communication technologies, Public libraries should be capable of maintaining their prominent role in the society and adapt themselves to the new technologies and equip users to information literacy by presenting educational programs, and this way pave the way for individuals to gain access to information and guide them in recovering information.

Therefore, public libraries should take step from their traditional position toward a place for lifelong learning and motivated individuals and equip them with the required knowledge and skills (BALAPANIDO, 2015).

By studying the vision plan of 2025 for public libraries organization, it is found that this organization has accepted the concept of information literacy by embedding lifelong learning as one of the pillars of the document.

Thus the libraries can play a role in improving information literacy by providing the adequate information, making information available, as well as, by providing courses and programs that create information literacy-related skills in individuals.

The role of public libraries in public education and lifelong learning is self-evident. Public libraries support adult education and lifelong learning Public libraries are institutions that not only provide information resources but also teach them how to use them. In addition to providing users with training courses, library librarians can enhance their information literacy skills (LAI, 2011). Information literacy is essential to help users fill the information gap and social participation to be active in social life and become a lifelong learner (VEGA, 2014).

Making an attempt to acquire information literacy requires time and practice and providing conditions in public libraries, and developing information literacy is not a temporary cross sectional process, but it requires lifelong 
continuing education. Achieving a society with information literacy requires the authorities to pay attention at macro-level and codifying the national policies to implement and program information literacy and organizations cooperation in this area (FARKHARI, 2016).

Like other skills, acquiring information literacy skills requires education and practice. On the other hand, the need to education should have been felt by the literate government and society otherwise gaining access to it is impossible. Unfortunately, in developing countries, information literacy is more needed by scientists, professors, and higher graduate students, while the cornerstone of teaching how to research must be laid from primary and secondary education levels in a way that it has been already taught when it comes to the academic levels of education in which the need to research takes a new form (Sharif Moghadam, apud REISI, 2011).

On the other hand, today, due to changes in the education system and moving toward student-centered education, the relationship between library and education has become deeper, and based on the opinion of educational experts, the library and school complement each other, and without the library, learning at school is difficult (KHORASANI, 2005). Here, the role of school libraries becomes more colorful in education. But, currently, unfortunately the lack of school libraries has caused large groups of teenagers to use public libraries as a place to find the answer to their questions and meet their information needs.

Public libraries can guide teenagers to gain access to the required information and meet their information needs. They can play an advisory role so that teenagers can find libraries an interesting and appropriate place and come there more. In this case, libraries will shift from the centers of keeping resources to a place to gain access to information, knowledge and learning otherwise it is observed that public libraries become a place to study textbooks and personal texts. Additionally, one of the factors of attracting teenagers to libraries is the presence of specialist trained librarians. Librarians can promote information literacy as much as they can, and take a positive step toward developing information literacy by teaching how to optimally search and effectively use search engines, and show their role in libraries to be colorful. 
As one of the missions of public libraries is to provide service to teenagers, paying more attention to the information needs of teenagers during the library membership and meeting their initial information needs cause them to gain effective access to resources and improve the information seeking behavior of teenagers in the library environment. Therefore, investigating and monitoring the rate of teaching information literacy to teenagers and the role of public libraries in enhancing information literacy can provide the authorities of public libraries organization with important and reliable information to develop this literacy, which has been expressed as the duties of public libraries by IFLA.

\section{Research objectives:}

Determining the rate of teaching information literacy skills to 11-16-year-old teenage members of public libraries of Tehran $1^{\text {st }}$ region.

Determining the effect of public libraries of Tehran $1^{\text {st }}$ region on teaching information literacy to 11-16-year-old teenagers.

\section{Research questions:}

How much information literacy have the 11-16-year-old teenage members of public library of Tehran $1^{\text {st }}$ region learned?

How much has this library affected information literacy teaching to the 11-16-year-old teenage members?

\section{Research hypothesis}

There is a significant relationship between library membership and the rate of information literacy in 11-16-year-old teenagers.

\section{Research theoretical framework}

\subsection{Information literacy definition and concept}

Information literacy is one of the requirements and prerequisites of software movement because it can nurture thought to identify information needs, information resources and systems, to search and use those resources and systems, and finally, to evaluate work process in the individuals of the society 
and convert them to citizens of information society (FATAHI, 2004). One of the first and simplest definitions was presented by Gusta (1985):

Information literacy is the ability to access, evaluate, and use information from different types of resources (GUSTA, 1985). The definition presented by the American Library Association as one of the most important and valuable achievements of this association with regard to information literacy is regarded as the most widely used definition in this area and has received the most citations.

According to the definition presented by American Library Association, information literacy is referred to a set of skills by which the individuals can detect when they need information to effectively locate and use the required data (KHALEGHI, 2010).

\subsection{Information literacy standards for students' learning}

\section{Information literacy standards}

Standard 1: A student has information literacy when he can gain access to information in an effective and efficient way.

Index 1. He detects information need.

Index 2. He knows that the correct and comprehensive information is the basis for wise decisions.

Index 3 . He poses questions based on information needs.

Standard 2. A student has information literacy when he critically and competitively evaluates information.

Index 1 . He evaluates the validity, reliability, and accuracy of information.

Index 2. He differentiates between the reality of point of view and personal opinion.

Index 3. He identifies the wrong and confusing information.

Standard 3. A student has information literacy when he can use information carefully and creatively.

Index 1. He organizes information for practical applications. 
Index 2. He integrates new information with his background Knowledge.

Index 3 . He uses information in critical thinking and problem solving.

\section{Independent learning}

Standard 4. A student is an independent learner who has information literacy and pursues information based on his personal interests.

Index 1. He designs, develops, and evaluates information products and solutions related to his personal interests.

Standard 5. A student is an independent learner who has information literacy and welcomes the literature and any creative expression information.

Index 1 . He is a self-motivated learner who is competent and motivated to study. Index 2. He welcomes creative products in any form.

Standard 6. A student is an independent learner who has information literacy and is interested in literature and tries to make progress in information seeking and knowledge production.

Index 1 . He evaluates the quality of process and the result of seeking his personal information.

\section{Social responsibility standards}

Standard 7. A student has information literacy, who positively interacts with educational society and community and understands the importance of information for democratic society.

Index 1. He searches information from different resources backgrounds, and cultures.

Standard 8. A student has information literacy, who positively interacts with educational society and community and adheres to ethical principles with regard to information and information technology.

Index 1 . He is committed to the principle of freedom of thought.

Index 2 . He respects intellectual property rights. 
Standard 9. A student has information literacy, who positively interacts with educational society and community and cooperates in group works to produce information.

Index 1. He shares knowledge and information with others.

Index 2 . He respects others opinions and perspectives in the study and research groups.

\subsection{The role of public libraries in enhancing information literacy}

Considering the main need of human to information literacy teaching and the position of public libraries, information literacy and public libraries need to be proposed among individuals and discussed in detail. Currently, information and effective use of information is regarded as a main principle in social and professional life of all sectors of the society. Not only it currently seems to be obvious, but also most societies consider the information as the raw material of production and by providing the desirable conditions are going to help all humans achieve knowledge and have a better life. Though the value of information and its role in development is evident, this important issue has not yet received attention in some societies and the required measures are not taken to produce, organize, distribute, and get access to it (PARIROKH, 2007).

Public library should actively support the measures related to literacy because the key to education and knowledge is the use of libraries and information literacy services (JIL, 2007).

All types of libraries play an active role in nurturing capable individuals with information literacy for Knowledge-oriented society and they have been the best option to keep, maintain, and make available information regardless of their cause. Meanwhile, public libraries have been placed in the excellent situation of the leader of cultural development of the society and an authentic reference to gain access to information and how to use it by providing and organizing information, and teaching and guiding individuals due to their capability of being permanently present throughout the individuals' life and providing several services compared to other libraries and information centers (FARKHARI, 2016). 
The role of public libraries in public teaching and lifelong learning is obvious. Public libraries are institutions that not only prepare information resources but also teach how to use them. They are information centers that guide people and brighten their lives. There is a strong relationship between information literacy and lifelong learning. They improve the information literacy skills of people by presenting free-charge courses of Internet and computer and reduce the digital gap in the current era (LAI, 2011).

\subsection{Background research}

Within the country:

Chowdhury, Shiful and Anwarul (2011): Knowledge-based society is already established in some developed countries which are not far away from Bangladesh. In the transition to the knowledge/ information based society, information literacy is essential for the effective and widespread use of information. It is used today to describe a set of skills and competencies, processes and actions, and attitudes that lead one to be a wise information consumer. This study observes information literacy concepts, standard indicators, and readiness of Central Public Library (CPL) and examines whether the CPL is ready to assume an enhanced responsibility for information literacy education. This study finds that the CPL in Bangladesh has shortcomings in information literacy education programmes due to lack of physical facilities, absence of information retrieval tools and low level of professional education of public library staff. However, recognition that present approaches are not meeting the requirements of users and more effective system with experienced educator is required. This study also emphasizes and suggests that without a push of external help through finance, professional expertise, facilities, and patronizations the CPL would not be able to properly address information literacy issues.

Mohammadian, Shakeri and Akbaridaryan (2012): This study aims to determine the level of information literacy (IL) of users of National Library and Archives of Islamic Republic of Iran (NLAI) based on ACRL standards.Using survey method, and on the basis of ACRL self-assessment Questionnaire, 200 
users were randomly chosen as research population. Finally, 124 persons answered the questionnaire. The average IL of users was high. The most average IL of users was the standard no.5 (3.79). The least average IL of users was the standard no.1 (3.52), meaning that most of the users had problems with determining their information needs. There was also no significant relationship between users' IL and their gender, age, educational level, and educational field. Since the average IL of users was high, IL instruction to NLAI librarians seems to be necessary. Moreover, holding workshops or courses on determining information need and information retrieval skills for end-users is of high priority.

TajdRn, Karbala Aghaei and Ameli Sabikeh (2013): research aimed to determine the role of public libraries in increasing urban information literacy in Neyshabour city.the methodology of the research is survey study. Data were collected via a questionnaire with a reliability coefficient of 0.85 . The research population included members of the public library in Neyshabour city by using Morgan table. A sample equal to 370 was chosen, using descriptive statistics (frequency distribution) and statistical analysis (T test, Anova, Friedman test) was performed. Information literacy among The research community below the expected mean (3) and libraries influences on intensifying information literacy these people below level the expected mean too. The most important barriers to the spread of information literacy is lack of information resources in the library, priority scheme of facilities used for development of information literacy responded Internet facilities to the information needs of members, The most important proposed solution is to provide educational brochures. There was no significant relation between sex and information literacy, The mean difference between the membership and the amount of information literacy is significant. Conclusions: Due to the lack of good information literacy of members, public libraries in Neyshabour city could not have an influence on the increase of information literacy.

Abdollahi and Jowkar (2014): The aim of the present paper is to examine the status of information literacy skills amongst public librarians in Fars province in terms of the information literacy standards. Methodology: This is an 
applied research with an analytical method. The Information Literacy Assessment (DAS) questionnaire was selected as the research tool. The questionnaire includes 55 questions and five standards designed to measure the information literacy skills of public librarians. The Pearson correlation test and t-test were used for data analysis. Findings: The results showed that the level of information literacy skills amongst public librarians is at an average level. The age and work experience of librarians seems to influence on their level of information literacy. There was a significant difference between librarians with library qualifications and librarians with other qualifications. It is also evident from the findings that the degree of education influences their level of information literacy amongst librarians. According to the findings, the public librarians have a low level of familiarity with the English language. Originality/Value: Public libraries play the role of a public university and have a significant role in the development of information literacy, both amongst members of the public and the broader community. An assessment of the status of information literacy amongst librarians, and planning for the development of such skills, will help libraries to achieve their goals.

Poursalehi, Fahimnia, Bazargan and Nakhoda (2016): Information literacy is a contextual concept that needs to be studied in different contexts like schools. Promoting reading literacy is a core instructional objectives of Persian literature curriculum and also a part of information literacy. Understanding Concept of information literacy helps us to understand information literacy in elementary schools and can implement it in information literacy Instruction and Assessment of schools. Methods: This research is a phenomenological research that used Qualitative Content Analysis technique for analyzing Semi structured interviews and Observations. Theoretical sampling was used and three schools were selected. We interview with four Teachers and observed four classes in Fourth Grade. Results: based on data analyzing we can describe information literacy for language in Fourth Grade in this phrases: "Set the scene: Make a space for thinking, reflecting and planning", " emerging of determining information need", "locating and searching of information" , “ information engagement”, “ information Processing”, “ record, organize and ethical use of 
information", “Communication" , "Presentation" . Conclusion. based on findings, teachers highly focused on developing skills of information engagement(reading, listening, viewing), Information Processing(supplying Infrastructures of text understandings; Practice textual, audio, visual comprehension; practicing information processing in action), presenting information(in written and Unwritten format and learning how to do them). Integrating information literacy with language curriculum seems that can help to achieve language instructional objectives. The findings can be used for designing instrument of information literacy assessment and also can be used for teacher training.

In abroad:

Nielsen and Borlund (2011) examined the role of public libraries in learning information literacy user learning and information capabilities of librarians in an article on learning information literacy and public libraries: a survey on Danish high school students. The survey was conducted at 12 high schools using semi-structured interviews and purposeful sampling of Danish public library users. The study found that high school students found public libraries to be an important place to learn, and public librarians found they were well-qualified in helping to improve their information needs, identifying resources, and supporting students in the information search process. The study found that high school students had relatively good essential skills and developing skills with poor information needs. The study found that the concepts of information literacy and lifelong learning are not well understood by users (high school students).

Nielsen and Borland (2013) in an article titled Information Literacy and Public Libraries: Danish Librarians' View of Information Literacy: Investigating the Results of an Experimental Study of Danish Librarians on the Concept of Information Literacy and User Training to Support and Optimize Lifelong Learning The library has paid. Data collection was done by a questionnaire. The results showed that librarians consider public libraries to be the most important place for learning, but they cannot share the concept of information literacy and lifelong learning. 
Kingori, Njiraine and Maina (2016): At an annual conference on research information seeking in Africa, they presented an article entitled Implementing Information Literacy Programs in Public Libraries: A Case Study from the National Library of Kenya. Information literacy skills of elementary students were $7 \%$ and high school students $26.3 \%$. Sixty percent of users indicated that the training method used was effective in providing information literacy programs. $40.4 \%$ of users are familiar with Google search engine. Poor library infrastructure Lack of budget and lack of policy are major challenges in delivering information literacy programs.

Kumar (2016), in an article titled Information Literacy Survey among Public Library Users, aims to understand the audience's understanding of information literacy resources and services among public library users. 79 members participated in the survey and studies showed that $100 \%$ of respondents use the library to read newspapers and magazines, $68.35 \%$ use the library for information, and $82.65 \%$ use the study.The findings show $\neg$ shows that most respondents believe that our favored ICT facilities are preventing them from using public libraries, and that we need to take innovative steps to attract users to public libraries and review their information literacy.

\section{Research methodology}

The current research is an applied study conducted using survey-descriptive method. If solving a problem is related to the present time, survey method is used.

The statistical population studied in this research consisted of 500 cases of the 11-16-year-old teenage members of Shahid Bahonar public library in Tehran $1^{\text {st }}$ region. Sample size was calculated to be 217 based on Morgan table (DAYANI, 2003).

Data were collected using researcher-made questionnaire. In order to design questionnaire, standard components and similar research studies conducted in the area of libraries and information literacy were used.

The questionnaire was sent to 5 experts in the area of information and Knowledgology to measure the questionnaire validity and their opinions were 
considered in codifying the questionnaire. In order to confirm the reliability of the research measurement tools, the pilot study was conducted on 30 cases of teenage members of Shahid Bahonar public library. The reliability of the questionnaire was calculated to be 0.84 using Cronbach's alpha, indicating the desirable reliability of the measurement tool.

After the questionnaires were returned and their data were extracted, the obtained data were analyzed using descriptive statistics (frequency, frequency percentage, etc.,) and inferential statistics (non-parametric Kruskal Wallis test). To this purpose, SPSS software was used.

\section{Investigation of demographic characteristics}

\section{Members gender}

Table 1 - Frequency distribution of members by gender.

\begin{tabular}{lll}
\hline Gender & Frequency & Frequency percentage \\
\hline Female & 127 & 0.59 \\
Male & 90 & 0.41 \\
Sum & 217 & 0.100 \\
\hline \multicolumn{2}{c}{ Source: The authors (2019) }
\end{tabular}

According to table 1, $67 \%(\mathrm{n}=127)$ of $11-16$-year-old respondents were females and $33 \%(n=90)$ of respondents were male.

\section{Members' library membership history}

Table 2 - Frequency distribution of members' library membership history

\begin{tabular}{lll}
\hline Membership history & Frequency & Frequency percentage \\
\hline $\begin{array}{l}\text { Years old and } \mathbf{2} \\
\text { younger }\end{array}$ & 90 & $0 / 42$ \\
Years old $\mathbf{4}-\mathbf{3}$ & 70 & $0 / 32$ \\
Years old and $\mathbf{5}$ & 57 & $0 / 26$ \\
older & & $0 / 100$ \\
Sum & 217 & \\
\hline & Source: The authors (2019)
\end{tabular}

Based on table 2, the membership history of the 11-16-year-old teenage members of Shahid Bahonar public library was $42 \%$ (2 years and less), 32\% (34 years) and $26 \%$ (5 years and more). 


\section{Findings:}

\section{Question 1:}

How much information literacy have the 11-16-year-old teenage members of public library of Tehran $1^{\text {st }}$ region learned?

A total of 20 questions were posed with regard to teaching information literacy skills to teenagers. These questions were posed under the title of general teaching of information literacy to teenagers.

Table 3 - Total information literacy skills in 11-16 year-old- teenagers

\begin{tabular}{lc}
\hline Information literacy components & Median \\
\hline Effective access to information & $3 / 4$ \\
Critical and skillful evaluation of information & $3 / 36$ \\
Use of information & $3 / 4$ \\
Total information literacy skills & $3 / 38$ \\
\hline
\end{tabular}

Source: the authors (2019)

Based on the data shown in table 3, the median for effective access to information, critical and skillful evaluation of information, and use of information is 3.4, 3.36, and 3.4, respectively. Overall, the greatest median is related to effective access to information and use of information, and the least median is related to critical and skillful evaluation of information.

The median for total information literacy skills of the 11-16-year-old teenage members of Shahid Bahonar public library in Tehran $1^{\text {st }}$ region is 3.38. In general, information literacy of teenagers is above average 3 .

\section{Question 2:}

How much has Shahid Bahonar public library affected information literacy teaching to the 11-16-year-old teenage members?

A total of 8 questions were posed with regard to the effect of this library on teaching information literacy to teenagers. These questions were posed under the title of the effect of Shahid Bahonar public library on teaching information literacy to teenagers. 
Table 4 - Effect of public library of Tehran $1^{\text {st }}$ region (Shahid Bahonar) on teaching information

\begin{tabular}{|c|c|c|c|c|c|c|c|c|c|}
\hline \multicolumn{10}{|c|}{ literacy } \\
\hline 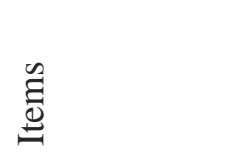 & 䒕 & $\stackrel{\overrightarrow{0}}{>} \stackrel{0}{\Xi}$ & 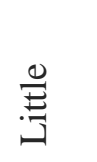 & 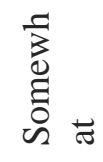 & 敢 & 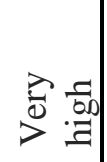 & : & $\stackrel{\varpi}{\Sigma}^{\bar{\Xi}}$ & 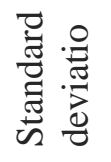 \\
\hline \multirow{2}{*}{$\begin{array}{l}\text { Effect of } \\
\text { public library } \\
\text { on detecting } \\
\text { information } \\
\text { need }\end{array}$} & Frequency & 10 & 17 & 50 & 60 & 80 & \multirow[b]{2}{*}{$3 / 00$} & \multirow[b]{2}{*}{$2 / 83$} & \multirow[b]{2}{*}{$1 / 146$} \\
\hline & $\begin{array}{l}\text { Frequency } \\
\text { percentage }\end{array}$ & $4 / 0$ & $0 / 8$ & $0 / 23$ & $0 / 28$ & $0 / 37$ & & & \\
\hline \multirow{2}{*}{$\begin{array}{l}\text { Effect of } \\
\text { public library } \\
\text { on web } \\
\text { searching } \\
\text { skills }\end{array}$} & Frequency & 10 & 27 & 40 & 50 & 90 & \multirow[b]{2}{*}{$2 / 00$} & \multirow[b]{2}{*}{$2 / 46$} & \multirow[b]{2}{*}{$1 / 184$} \\
\hline & $\begin{array}{l}\text { Frequency } \\
\text { percentage }\end{array}$ & $5 / 0$ & $0 / 12$ & $0 / 18$ & $0 / 23$ & $0 / 42$ & & & \\
\hline \multirow{2}{*}{$\begin{array}{l}\text { Effect of } \\
\text { public library } \\
\text { on library } \\
\text { resources } \\
\text { recovery } \\
\text { skills }\end{array}$} & Frequency & 20 & 40 & 50 & 37 & 70 & \multirow[b]{2}{*}{$3 / 00$} & \multirow[b]{2}{*}{$2 / 81$} & \multirow[b]{2}{*}{$1 / 145$} \\
\hline & $\begin{array}{l}\text { Frequency } \\
\text { percentage }\end{array}$ & $9 / 0$ & $0 / 19$ & $0 / 23$ & $0 / 17$ & $0 / 32$ & & & \\
\hline \multirow{2}{*}{$\begin{array}{l}\text { Effect of } \\
\text { public library } \\
\text { on increasing } \\
\text { information } \\
\text { organizing } \\
\text { skills }\end{array}$} & Frequency & 7 & 20 & 90 & 60 & 40 & \multirow[b]{2}{*}{$3 / 00$} & \multirow[b]{2}{*}{$2 / 61$} & \multirow[b]{2}{*}{$1 / 063$} \\
\hline & $\begin{array}{l}\text { Frequency } \\
\text { percentage }\end{array}$ & $3 / 0$ & $0 / 9$ & $0 / 42$ & $0 / 28$ & $0 / 18$ & & & \\
\hline \multirow{2}{*}{$\begin{array}{l}\text { Effect of } \\
\text { public library } \\
\text { on increasing } \\
\text { the ability to } \\
\text { access the } \\
\text { required } \\
\text { information }\end{array}$} & Frequency & 20 & 27 & 50 & 20 & 100 & \multirow[b]{2}{*}{$3 / 00$} & \multirow[b]{2}{*}{$3 / 09$} & \multirow[b]{2}{*}{$1 / 083$} \\
\hline & $\begin{array}{l}\text { Frequency } \\
\text { percentage }\end{array}$ & $9 / 0$ & $0 / 13$ & $0 / 23$ & $0 / 9$ & $0 / 46$ & & & \\
\hline \multirow{2}{*}{$\begin{array}{l}\text { Effect of } \\
\text { public library } \\
\text { on teaching } \\
\text { ethical use of } \\
\text { information }\end{array}$} & Frequency & 17 & 45 & 20 & 45 & 90 & \multirow[b]{2}{*}{$2 / 00$} & \multirow[b]{2}{*}{$2 / 18$} & \multirow[b]{2}{*}{$1 / 111$} \\
\hline & $\begin{array}{l}\text { Frequency } \\
\text { percentage }\end{array}$ & $8 / 0$ & $0 / 21$ & $0 / 9$ & $0 / 21$ & $0 / 41$ & & & \\
\hline Holding & Frequency & 7 & 20 & 50 & 100 & 40 & & & \\
\hline
\end{tabular}




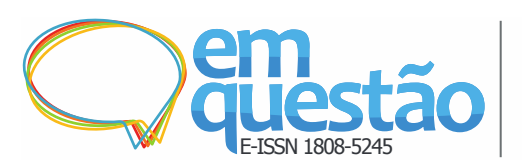

Teaching information literacy to 11-16-year-old teenage members of public libraries of Tehran 1st region

Kiarash Mirzakhani and Anahita Dashti

\begin{tabular}{|c|c|c|c|c|c|c|c|c|c|}
\hline $\begin{array}{l}\text { scientific } \\
\text { discussion } \\
\text { sessions in } \\
\text { public library }\end{array}$ & $\begin{array}{l}\text { Frequency } \\
\text { percentage }\end{array}$ & $3 / 0$ & $0 / 9$ & $0 / 23$ & $0 / 46$ & $0 / 19$ & $2 / 00$ & $2 / 03$ & $1 / 144$ \\
\hline \multirow{2}{*}{$\begin{array}{l}\text { Holding } \\
\text { educational } \\
\text { courses in } \\
\text { public library }\end{array}$} & Frequency & 20 & 40 & 60 & 47 & 50 & \multirow[b]{2}{*}{$1 / 00$} & \multirow[b]{2}{*}{$1 / 73$} & \multirow[b]{2}{*}{$1 / 037$} \\
\hline & $\begin{array}{l}\text { Frequency } \\
\text { percentage }\end{array}$ & $9 / 0$ & $0 / 18$ & $0 / 28$ & $0 / 22$ & $0 / 23$ & & & \\
\hline \multicolumn{2}{|c|}{$\begin{array}{l}\text { Effect of public library on } \\
\text { teaching information } \\
\text { literacy }\end{array}$} & $8 / 28$ & $20 / 8$ & $03 / 0$ & $15 / 8$ & $4 / 71$ & $2 / 5$ & $2 / 44$ & $0 / 765$ \\
\hline
\end{tabular}

Source:The authors (2019)

As shown by findings in table 4, the effect of public libraries on increasing the ability to access the required information and library resources recovery skills was evaluated to be average, while holding educational courses in public library to teach information literacy was assessed to be lower than average. The median of the effect of public library on information literacy of the 11-16-year-old teenagers is 2.5. Generally, the effect of public library on information literacy of the 11-16-year-old teenagers is lower than average (3).

\section{Research hypothesis}

There is a significant relationship between library membership history and the rate of information literacy in 11-16-year-old teenagers.

First, the assumption of normal distribution in the given population is examined. To this purpose, the Kolmogorov-Smirnov test was conducted. The obtained results show the assumption of normal distribution of population is not confirmed given the smaller significance level than $0.05(\mathrm{p}<0.05)$.

Thus in order to confirm the above mentioned hypothesis, nonparametric Kruskal Wallis test was used. 
Table 5 - Kruskal Wallis test to test the membership history hypothesis

\begin{tabular}{llllll}
\hline $\begin{array}{l}\text { Dependent } \\
\text { variable }\end{array}$ & $\begin{array}{l}\text { Independent } \\
\text { variable }\end{array}$ & Classes & Number & $\begin{array}{l}\text { Average } \\
\text { rating }\end{array}$ & $\begin{array}{l}\text { Significance } \\
\text { level }\end{array}$ \\
\hline $\begin{array}{l}\text { Information } \\
\text { literacy }\end{array}$ & $\begin{array}{l}\text { Membership } \\
\text { history }\end{array}$ & $\begin{array}{l}\text { 2years } \\
\text { old and } \\
\text { younger }\end{array}$ & 70 & $169 / 15$ & $0 / 19$ \\
& & $147 / 82$ & \\
& & $4-3$ years & 57 & $145 / 83$ & \\
old5 & & & \\
years old \\
and older
\end{tabular}

Source: the authors (2019)

According to table 5, the significance level of 0.19 is greater than 0.05 ( $p>0.05)$. Therefore, there is no significant difference between information literacy of the 11-16-year-old teenage members of public library of Tehran $1^{\text {st }}$ region (Shahid Bahonar Library) and their membership history and the above mentioned hypothesis is consequently rejected.

\section{Conclusion}

The fundamental literacy of knowledge-based societies has been dubbed the present century. Information literacy as a need and necessity in the information age equips individuals with the ability to identify information needs by assessing information needs and assessing the effective and responsible use of information. An information literate person possesses critical analytical skills in formulating research questions and evaluating results, and has the ability to search and access a diverse range of information to meet their needs. It has the potential to expand these capabilities and reach an information literate society. To develop these capabilities and reach an information-literate society of experts such as Herport and Smith (1994); Jonnett and Wallis (2005) and Kingouri, Nairn and Mina (2016), the need to teach and train information literacy and information standards They have emphasized the need to provide people with lifelong learning.

Given the importance of information literacy skills according to the IFLA Statement and the necessity to learn it, an appropriate context should be established for teaching these skills. According to IFLA Public Libraries 
Statement Nos. 11 and 12 (1994), the duties of public libraries facilitate the development and development of information and computer literacy skills and support and participation in information literacy programs and activities for all age groups and startups. Such activities may be required.

Teaching information literacy is a new important issue, which has received lots of attention from most organizations and different institutions of different countries of the world. Public libraries in different countries of the world have paid attention to this important issue and like their other counterparts such as academic libraries, they help create sustainable development. The problem is that despite the importance of this issue, the public libraries in our country have ignored it and the reasons and whyness of this issue should be scrutinized. It should be explained that doing so can lead to more prosperity of these libraries and attraction of more audiences. Findings show that public libraries lack the appropriate situation to implement the information literacy education of their audience. Generally, public libraries do not have the desirable situation in terms of space, facilities and equipment, and the appropriate conditions do not exist in terms of resources, equipment, space, up-to-date hard copy and electronic resources, required space for class and computer equipment, possibility to connect to Internet and supplying the required financial resources to use professors to teach in workshops. Additionally, there are not required human resources with related academic education and higher scientific degrees. The librarians' information literacy level is not desirable. These individuals are not capable of teaching users wheatear in terms of teaching information literacy to users or programming to implement information literacy programs at the level of their libraries. Considering research findings, it is suggested that skillful and interested librarians make teenagers familiar with the advantages of reference resources and help them use these resources to find the answer to their questions, especially in the area of conducting research studies. As in vision plan of 2025, the public libraries organization has accepted the concept of information literacy by embedding lifelong learning as one of the pillars of the document, the short-term and long-term programming should be done to attain this goal, and these programs should be implemented in all libraries under the 
complete supervision of public libraries organization. Considering the expansion of information and information tools, public universities should keep pace with these changes and give priority to the improvement of the individuals' information skills.

Although libraries have failed to play an important role in promoting adolescent information literacy, the lack of a coherent, structured education that can teach adolescents how to search and evaluate information according to scientific and well-founded principles is lacking. , It is the librarian's duty to play a serious role in educating and mentoring teens by holding courses.

\section{References}

ABDOLLAHI, Masoumeh; JOKAR, Abdul Rasoul. Information Literacy Status of Librarians of Fars Public Libraries. Journal of Information and Public Libraries Research, Tehan, v. 20, n. 4 (79), p. 771-778, 2014.

AMERICAN ASSOCIATION OF SCHOOL LIBRARIANS. Information power: building partnerships for learning. Chicago: American library association, 1998.

AMERICAN ASSOCIATION OF SCHOOL LIBRARIANS. Standards for the 21 st-century learner. Chicago: American library association, 2007. Avaiable in: http://www.ala.org/aasl/standards.

ANGORJ TAGHVI, Masomeh. Investigation the level of information literacy in public librarians of Tehran City affiliated with public libraries organization of the country. 2008. Master thesis in librarianship and information, Islamic Azad University, North Tehran branch, Faculty of Humanities.

ASEMI, Asefeh; RIAHINIA, Nosra; ANDIAN, Fatemeh. Information literacy: education and learning. Tehran: Ketabdar Publications, 2011.

ASSOCIATION OF COLLEGE AND RESEARCH LIBRARIESACRL Board. Framework for information literacy for higher education. Chicago: Association of College and Research Libraries, 2016. Avaiable in: http://www.ala.org/acrl/standards/ilframework.

BALAPANIDOU, Aikaterin. The Challenging Role of public libraries as providers of lifelong learning opportunities for personal and social skills development. International Journal of Teaching and Education, Prague, v. III , n. 2, p. 1-15. 2015. 
CHOWDHURY, Salma; ISLAM, Shiful; ISLAM, Anwarul. The Information Literacy Education Readiness of Central Public Library (CPL) in Dhaka of Bangladesh. International Journal of Information Science and Information Management, Shiraz, v. 1, n. 2, p. 23-44, 2011.

DARBANDI, Mehdi. Kalman Filtering for Estimation and Prediction Servers with Lower Traffic Loads for Transferring High-Level Processes in Cloud Computing. International Journal of Technology Innovations and Research, India, v. 23, n. 1, p. 10-20, 2017.

DARBANDI, Mehdi. Proposing New Intelligence Algorithm for Suggesting Better Services to Cloud Users based on Kalman Filtering. Journal of Computer Sciences and Applications, [S.l.], v. 5, n. 1, p. 11-16, 2017. DARBANDI, Mehdi. Proposing new intelligent system for suggesting better service providers in cloud computing based on kalman filtering. HCTL

International Journal of Technology Innovations and Research, India, v. 24, n. 1, p. 1-9, 2017.

DARBANDI, Mehdi; HAGHGOO, Saeed; HAJIALI, Mahdi; KHABIR, Alireza. Prediction and estimation of next demands of cloud users based on their comments in crm and previous usages. International IEEE Conference on Communication, Computing \& Internet of Things. Chenai, 2018.

FARKHARI, Fatemeh. Information Literacy Training in Public Libraries. First International Conference and Second National Conference on the Third Millennium and Humanities, Shiraz, Iran Modern Education Development Center (Metana), 2016.

FARNAZ, Mohammadi; SEDIGHEH, Shakeri; SAEEDEH, Akbari Darian. Information Literacy Level Assessment of the Referrers and National Library of the Islamic Republic of Iran Based on ACRL Standards, Journal of Information Systems and Services. [S.l.], v. 1, n.2, p. 85-96, 2012.

FATAHI, Rahmatollah. Information Literacy and Improving Researchers' Information Behavior: The Need to Integrate Information Literacy in the Research and Knowledge Production Process. Collection of user education articles and information literacy development in libraries and information centers. National Conference on Information Literacy in Mashhad, June 1-2. Mashhad: Library Organization. Museums and Document Center Astan Quds Razavi. 2004, p. 135-153.

GILL, Philip. Public Libraries Services: IFLA / UNESCO Guidelines for Development. München: K.G. Saur, 2001.

HORTON, Forest Woody. Understanding information literacy: a primer. Paris: UNESCO, 2007. 
KHALEGHI, Narges; SIYAMAK, Marzieh. Teaching information literacy skills. Tehran: Ketabdar, 2010.

KHORASANI, Emad; DOKHT, Nasrin. Public Library Services and its Practices. Tehran: Librarian Publishing, 2005.

KINGORI, George; NJIRAINE, Dorothy; MAINA, Stephen. Implementation of information literacy programmes in public libraries. Library Hi Tech News, United Kingdom , v. 33, n. 2, p. 17-22, 2016. Available in:

https://doi.org/10.1108/LHTN-09-2015-0063

KUMAR, K. Information literacy practice among public library users: a study. International Journal of library science, v. 14, n. 1, 2016.

LAI, Horng-Ji. Information Literacy trainning in public libraries: a case from Canada. Educational tecnology \& society, Taiwan, v. 14, n. 2, p. 81-88, 2011.

LAU, Jesús. Guidelines on information literacy for lifelong learning: final draft. Haia: IFLA information literacy section, 2006. Available in: https://www.ifla.org/files/assets/information-literacy/publications/iflaguidelines-en.pdf.

LIOYD, Annemaree. Information literacy landscapes: information literacy in education, workplace and everyday contexts. Cambridge: Chandos Publishing, 2010.

MAHDIZADEH, Hossein. Information literacy of individuals referring to public universities of Mazandaran province and the role of these universities in developing this important issue. 2010. Master thesis in librarianship and information. Islamic Azad University, North Tehran branch, Faculty of Humanities.

MALEKIAN, Ensiyeh. The role of school libraries in improving information literacy of students of Mashhad public girls guidance school. 2015. Master thesis, Tarbiat Modarres University.

NIELSEN, Bo Gerner; BORLUND, Pia. Information Literacy and the public library: Danish librarians views on information literacy.In: KURBANOĞLU, Serap GRASSIAN, Esther; MIZRACHI, Diane; CATTS, Ralph; ŠPIRANEC, Sonja.(eds). Worldwide commonalities and challenges in information literacy research and practic: European Conference, ECIL 2013, Istanbul, Turkey, October 22-25, 2013. Revised Selected Papers. Switzerland: Springer International Publishing, 2013. p. 632-38.

NIELSEN, Bo Gerner; BORLUND, Pia. Information Literacy, learning and the public library: A study of danish high school student. Journal of Librarianship and Information Science, Thousand Oaks, v. 43, n. 2, p. 106-119, 2011. 
PARIROKH, Mehri. Teaching information literacy: concepts, methods and programs. Tehran: Ketabdar, 2007.

POURSALEHI, Nastaran. Comparative study of the effect of teaching information literacy in: librarian and teacher on improving information literacy skills of students of girl smart high schools of Tehran city. 2009. Master thesis in librarianship and information, Tarbiat Modarres University, Faculty of Economics and Management.

POURSALEHI, Nastaran; FAHIMNIA, Fatima; BAZARGAN, Abbas; NAKHODA, Maryam. On the Information Literacy in Schools Case Study: Fourth Grade Elementary Persian. Journal of Human Interaction and Information, Tehan, v. 3, n. 4, p. 12-25, 2016.

RAISI, Zohreh. The Role of Public Libraries on Information Literacy of High School Students from the Viewpoints of Undergraduate Students of Yazd University. 2011. Master thesis. Qom University, Faculty of Literature and Humanities.

RAZGAR, Hossein. Comparative study of the level of information literacy skills in high school female and male students of Ardebil city (case study: 16-18 year old students). 2011. Master thesis in Social Communication Sciences, Allameh Tabatabaei University.

SHOKUHIAN, Mahboubeh. An investigation into information needs of 15-18 yearold teenagers of libraries covered by public universities organizations of Isfahan city. 2011. Master Thesis in Librarianship and Information, Isfahan University.

TAJDARAN, Mansour; KARBALA, Masoumeh A. K.; SEBIKE, Ameli. The Role of Neyshabur Public Libraries in Enhancing Citizens' Information Literacy. Journal of Science (Library and Information Science and Information Technology), [S.l], v. 6, n. 20, p. 39-54, 2013.

VEGA, Aurora de la. Information Literacy and Public Libraries in Peru: An Approach to Its Study. In: KURBANOĞLU, Serap; ŠPIRANEC, Sonja; GRASSIAN, Esther; MIZRACHI, Daiane; CATTS, Ralph (eds). Information Literacy. Lifelong Learning and Digital Citizenship in the 21st Century: Second European Conference, ECIL 2014, Dubrovnik, Croatia, October 20-23, 2014. Proceedings. Switzerland: Springer International Publishing, 2014. p. 622633.

YARI, Shiva. Visibility of kermanshah public libraries. Information Research and Public Libraries, [S.l], v. 23, n. 2, p. 173-198, 2017. 


\section{Ensino de information literacy para adolescentes de 11 a 16 anos membros de bibliotecas públicas da $1^{\text {a }}$ região de Teerã}

Resumo: O ensino da information literacy é uma questão nova e importante, que recebeu muita atenção da maioria das instituições do Irã. Bibliotecas públicas em diferentes países do mundo também prestaram atenção a esta importante questão. O objetivo desta pesquisa é ensinar alfabetização informacional a adolescentes de 11 a 16 anos de idade membros de bibliotecas públicas da $1^{a}$ região de Teerã. Este é um estudo descritivo, realizado por survey. A população da pesquisa consistiu em adolescentes (11 a 16 anos) da biblioteca pública Shahid Bahonar, com mais de 500 indivíduos. Usando a tabela de Morgan, o tamanho da amostra da pesquisa foi calculado em 217. Os dados foram coletados por meio de questionário. Os dados coletados foram analisados por estatística descritiva e inferencial. Os resultados da pesquisa mostraram que as habilidades de alfabetização informacional de adolescentes de 11 a 16 anos de idade de bibliotecas públicas da $1^{\mathrm{a}}$ região de Teerã $(3,38)$ são superiores à média (3) e o papel da alfabetização em informação no ensino da alfabetização em adolescentes (2,5) é menor que a média (3).

Palavras-chave: Bibliotecas públicas. Alfabetização informacional. Ensino de alfabetização informacional. Aprendizagem ao longo da vida.

Recebido: $17 / 12 / 2019$

Aceito: 02/04/2020 